\title{
NKRI and The Phenomenon of Religious Radicalism
}

\author{
Rusydi Sulaiman \\ Lecturer of STAIN Syaikh Abdurrahman Siddik Bangka Belitung \\ Email: abirusydi@yahoo.co.id
}

\begin{abstract}
Negara Kesatuan Republik Indonesia termed as NKRI is the ideal form of the Indonesian nation which has become a consensus among religious and social groups to maintain the integrity of the nation in various aspects of life. This country then meets various challenges, including the emergence of the radical movement in Islam. The phenomenon of radicalism looks solid time by time and becomes a destruction of NKRI's Five Principles or Pancasila. This movement is a contrary to the condition of pluralism in Indonesia. The homogeneity requires a certain form of ideology as a foothold towards National endurance. This article aims to explain NKRI, and the phenomenon of Religious Radicalism, which emphasizes on the strengthening of Pancasila's values as an alternative ideology toward some aspects struggled by radical Islamists. In this study, the author adopts a descriptive qualitative research method based on literature (library research). This article offers that Pancasila as an alternative ideology of NKRI because its values are based on Al-Qur'an as the main source of Islam. As a global source, Al-Qur'an also requires Sunnah as a detailed source. Pancasila that bases on both two sources, then choose to face everything from human needs; a social or religious aspect of human's life.
\end{abstract}

\section{Keywords: NKRI, Religious radicalism, Ideology, Pancasila.}

\section{INTRODUCTION}

Indonesia has proclaimed its independence with full sovereignty and gave the highest appreciation to its citizens.

The existence of NKRI become more stable and strong with certain foundations as a foothold. Many figures inspired us to be a big, energized and an integrated nation. But in fact, this country could not be separated from challenges, namely political, educational, economic, cultural and social sectors including religion. Many problems appear related to those troubles in Indonesia. Often, some government policies in religion and religious matters invite polemics and even rejection by adherents of certain religions because of their ignorance, misunderstanding, and difference of understanding. It is difficult to distinguish whether the emergence of the situation, caused by political factors or theological factors.

Religious radicalism is a phenomenon that allegedly opposed to the government because of its anti-NKRI. Specifically, this paper focusses on radical Islamic movement that stands for Islam as an absolute state ideology.The spirit of applying Islamic Shari'ah has led this movement unguided; they have strong protests that rejects overall condition of this country, set resistance and even wants to replace the existing system with an idealized new system. Not many antimovement attitudes towards other movements are caused by strong ideals of vision and mission within a structured movement. Islamic radicalism is in contrast to mainstream Islam, then becomes a global phenomenon. So, the people should return to the pillars of nationality. Revitalization of Pancasila and the reinforcement of its values is the solution offered.
This paper offers several sub-articles, namely: the strength of NKRI, the phenomenon of religious radicalism, radical Islamic movement as a form of rejection of NKRI and reinforcement of Pancasila. Hopefully, this discussion will provide wisdom for us in religious life, nation, and state in this sovereign country.

\section{THE STRENGTH OF NKRI}

NKRI is a nation recognized for its independence on August 17, 1945, despite a slight post-proclamation upheaval occurred. The UN also stepped in to recognize the sovereignty of this large country. The role of the figures, both nationalist and religious could be proved in historical reviews of Indonesia. It is not an obstacle to spread the values of unity for the sake of a prosperous nation. Appropriate as reflected in the predicate given by Geertz (1965) as a revolution. Therefore, the Old Order government spent the first 25 years since independence to foster unity and national unity.

The movements and religious organizations mobilized by graduates of Islamic boarding schools and local Islam in the early 20th century AD. All of them are related to the realization of the independence of Indonesia. Surely there is a foundation that has been formulated ahead of independence. Yudi Latif states that the basis of the State being excavated from the earth of Indonesian history whose extension rate did not stop until the dark ages of colonization but broke far back until the time of the former archipelago. Another strength of this country is it has a very strategic position.

\section{The PhenOMENON Of Religious RADICALISM}

Etymologically, the word "radicalism" still invites debate; typical or characteristic, the appearance of the movement, behavior of the adherents labeled at radicalism. "Radicalism" consists of two words, "radical" and "ism." A term of,"radical" derived from the word, "radical" means a radical attitude that controls the desire to change one situation fundamentally. The term, "ism" is ideology. So radicalism tends to be interpreted as a synonym of protest, used as an indicator of rejection attitude towards the overall condition. A term, "radical" which derives from the words 'radical' means

1 Dr. Radiman Wediodiningerat as a head of BPUPKI on May 29, 1945, asked the forum to deliver on the basis of the nation. This the statement motivate anamnesis. He returned our remembrance to the founders of the country. It also builds up the deepness of spirituality, personality, and broad-mind of nationality in previous historical events. All simplified thought of nation's basis being prepared since 1920-'s; an effort to synthesize varied ideology and some movements to form a national block to have an independence of Indonesia. See Yudi Latif, Negara Paripurna: Historisitas, Nasionalitas dan Aktualitas Pancasila, Jakarta: PT.Gramedia Pustaka Utama, 2011, p.4 
rooted. Radicalism shows the attitude or appearance of a movement that is very rooted and determines its base among the community.

Radicalism is always associated with social phenomena multiplied by a particular individual or group because of a case and for a particular purpose, then it is called social radicalism. The three characteristics of social radicalism are as follows: firstly, radicalism in response to ongoing conditions in the form of evaluation, rejection or even resistance; secondly, radicalism is not merely a rejection, but attempts to change the existing order with other forms of order; thirdly, radicalism is synonymous with the reinforcement of the truth of the program or ideologization which implicates the negotiation of other systems. Not many anti-movement attitudes towards other movements are caused by strong ideals of vision and mission within a structured movement.

The characteristics of social radicalism could be used as a benchmark to understand religious phenomena which have a similar characteristic. Social radicalism becomes religious radicalism. Religion is institutionalized by groups or based on individual experience so that it elicits certain religious attitudes and understanding. However, these three traits are mere 'working-hypothesis, Perhaps, because other religious movements have fewer features, more similarities or traits. However, it does not mean other different movements could not be associated with radicalism. It is synonymous with particularistic religious attitudes and blames others for disagreeing.

The root of social-religious radicalism stems from the gaps in Indonesian society. Historically, such gaps occur because of the groups that control access to capital and power since the eruption of the nation. Unaccommodated political Islam groups within Indonesia's political structure take radical and militaristic political steps. Politically-oriented, the root of Radical Islam is a class struggle between the "moderate" bourgeoisie and "pro-government" against the marginalized. This then affects their class consciousness by using the "Islamic Shari'a" as the basis of a central teaching that could replace countries which fail to anticipate such structural inequalities. The problem is a gap that intervenes with social, economic, and even political spheres. Poverty is an implication of misrepresentation and imitation of polytheism that is not adapted to the context and objective conditions of the country. The issue of the birth of "Islamic radicalism" will not escape the state of poverty alleviation.

\section{RADICAL ISLAMiC MOVEMENT As The REJECTION OF NKRI}

Although radicalism is not typical of Islam, a case of Islamic radicalism has gained considerable momentum over the past few years. Especially after the events of World Trade Center of 11 September 2001, some upheavals in Western countries and Indonesia led to the emergence of a very negative stigma against Islam. Indeed religion (Islam or any religion) taken for granted is seen as a divine instrument that teaches good things. The moderation and balance which taught by Islam includes everything, regarding belief, worship, deeds, and behavior as well as in the law.

However, so many facts are closely related to Islam and radicalism. Some forms of ideas put forward by the group as a rejection of NKRI among others are: firstly, the requirement of Khilafah as the basis of the state. In the the radical Islam' perspective, government or political power must be conquered and Islamized. There are two strategies, namely: Re-Islamization from above and re-Islamization from below; Secondly, the implementation of Islamic sharia as the only source of state law. Thirdly, the obligation of jihad-not ijtihad. The opinion of war and peace is only viewed from the point of fiqhiyah (jurisprudence) while the philosophical or ethical works underlines the basic framework is very little. Jihad as physical work is the only solution to confront the enemy of Islam. The word "jihad" is always used as the basis for upholding the truth by fighting, although it is not necessarily the case. Furthermore, the word "jihad" then extended to the discussion into the word "ijtihad" and "mujahadah"..

When the religious movement is associated with the phenomenon of ISIS (Islamic State of Iraq and Syuriah) which appears lately, it seems to have a resemblance. In general, the movement draws a hard line against other groups. In a simple way such as: how to dress or physical appearance characterize a special identity (very exclusive). Religious symbolic attributes are over-emphasized rather than substantial ones. The religious radicalism refers to the extreme acts committed by a person or group of people who tend to inflict violence in the name of religion, such as: sweeping and raids on places; gambling, discotheques and prostitution; demonstration and destruction of the offices of certain institutions, mobilization of the masses with certain religious symbols and attributes, political statements with certain tendencies and threats and orations.

Radical Islam is a sect or mazhab in Islam that aspires the implementation of Islamic law in socio-political life. The ideal movement usually has drastic acts of violence to address its radical aim. The framework of radical Islamic thoughts are basically: (1) Islam should be the basis of the state; (2) Shari'ah should be accepted as a state constitution; (3) Political sovereignty is in the hands of God. (4) Ideas about the country. (5) Nation-state which contradicts the concept of people who do not recognize political or regional boundaries; (6) The principle of shura (musyawarah) is different from the idea of democracy. The most prominent factor in the emergence of Islamic extremism is the crisis of trust in state institutions, religious and political institutions.

\section{STRENGTHENING PANCASILA VALUES}

There are several government policies that contact with Pancasila, namely: a). Hari Kesaktian Pancasila (October 1, 1965) post-rongrongan PKI; b). The early period of the application of Pancasila (Parliamentary Politics, 1945-1959) The Military Aggression of the Netherlands, the dissolution of the Constituent Assembly, the 1950 Constitution does not apply, and the re-enactment of the 1945 Constitution; c). Guided Democracy Period (Old Order: 1959-1966); d). Democracy of Pancasila (1968), MPRS decree no. XXXVII/MPRS/1968; e). The New Order Period (1967-1998) which extolled the Pancasila like God through its P4 program; f). The Reformation Period (1999-present), minimized the influence of the New Order and restored the freedom of the people. As a result, Pancasila is almost abandoned. How if we neglect the Basic State? Will it implicate the future of the people? Of course, it is our responsibility.

As a state philosophy, Pancasila has strong values contained therein, namely: Firstly, the value of Oneness of God. The Indonesian nation must believe in the idea of monotheism, one God, the Almighty God. The unity of God that is included in the first principle of Pancasila is the faith and piety of the one God in Indonesia. And the State guarantees the freedom of every citizen to embrace his or her 
religion. The flexibility of positive attitude in religion is very guarded. Secondly, the value of inclusiveness, spirituality, humanism /humanity, togetherness, democracy, and justice. When these values implanted in each and touched to the fellow at the local and wider level, undoubtedly this nation will always be appreciated highly by other nations.

Thirdly, a living and a dynamic ideology. Pancasila is not a static State ideology, but alive, growing and dynamic. It is very open, accessible to anyone, not reserved for a particular group. The abolition of seven words in the first preceding sila (in the Jakarta Charter), because Pancasila is known as a unifying ideology or national ideology, is not a monopoly of a particular society. The fourth value in Pancasila is the principle of Good Governance. A State is initiated by the formation of figures who have a reputation and high integrity of self towards a good country. Good Governance is a civil State, a State with its population of "civil society." Al-Farabi called it, "al-Madiinah alFaadhilah", the main State. Culture and high civilization characterize the community. And it is impossible for such a State without the participation of the people by a common commitment, upholding the principle of a nation-state with a strict distinction between private and public affairs, between private property and public property. Among the principles of Good Governance are participation, law enforcement, transparency, responsiveness, agreement orientation, fairness, effectiveness, and accountability. Fifthly, the modern democratic vision of the state's relationship with society. The state is not built on the authoritarian stance of a leader, but there is a constitution that legitimizes his power. The synergy between the legislative, executive and judiciary in the State and the participation of those who are out of power is very important. The state must be democratic towards its people. Sixthly, unity. By nationalism, this nation must foster the close unity among fellow citizens without distinguishing between tribes and classes and all should stand on one common goal. The nationalism here does not mean narrow nationalism that only glorifies the nation itself and lower the other nations (inward and outward).

However, the authority of Pancasila should not exceed the religions held because it is not a religion. Pancasila is indeed a reflection of ideal manifestation and cultural behavior derived from the power of logic and the depth of human reflection. In a rather moderate perspective, Pancasila is in religion. The founders of the foundation of the State are religious people. And religion comes from God Almighty who has the absolute and true truth (The ultimate reality). Pancasila is not just a signal, but a pride of the nation.

\section{CLOSING}

Indonesia should complement its soft power approach to address the development of terrorism in Indonesia through a program of deradicalization. This strategy is aimed to neutralizing the influence of radical ideology, especially Islamic radicalism. In the last few years, the deradicalization has been used as one of the main programs of the Indonesian government implemented by various departments including the National Agency for Combating Terrorism (BNPT), Police, TNI, State Intelligence Agency, Ministry of Religious Affairs, and others. The government realized that the deradicalization should be effective if it involves main stakeholders, such as religious leaders, mass organizations, political parties, NGOs, mass media, intellectuals, and so forth. The synergy of TNI-Polri along with the whole of the nation's components will facilitate detection system, warning and prevent early action. The enhancement of national stability will further contribute to National Resilience. Ultimately, national goals will come true.

\section{References}

[1] Ahmad Rizki mardhatillah Umar, Melacak Akar Radikalisme Islam di Indonesia, Jurnal Ilmu Sosial dan Politik, vol.14, number.2, November 2010, pp. 183-184, htps.journal ugm.ac.id. accessed on August 29, 2017

[2] Akram Dhiyauddin Umari, Masyarakat Madani: Tinjauan Histories Kehidupan Zaman Nabi, Jakarta: Gema Insani Press, 1999

[3] AW.Munawwir,A Dictionary of al-Munawwir, Arabic and Indonesian, Surabaya: Pustaka Progresif, 1984

[4] Dedi Prasetyo, Sinergi TNI-POLRI dalam Deradikalisasi Terorisme di Indonesia, in "Jurnal Keamanan nasional", vol.II, Number.1, 2016,pp..39, http: //jurnal.ubharajaya.ac.id, acceessed on August 29, 2017

[5] Kansil, Pancasila dan UUD 1945: Pendidikan Pancasilla di Perguruan Tinggi, Jakarta: Pradya Paramita, 2003

[6] Khamami Zada, Islam Radikal: Pergulatan Ormas Ormas Islam Garis Keras di Indonesia, jakarta: Teraju, 2002

[7] Mun'im A.Sirry, Membendung Militansi Agama: Iman dan Politik dalam Masyarakat Modern,Jakarta: Penerbit Aerlangga, 2013

[8] Ninin Prima Damayanti, Imam Thayibi, listiya Adi gardhiani, Indah Limy, Radikalisme Agama sebagai salah Bentuk Perilaku menyimpang: A Case Study Pront Pembela Islam,"in Journal of kriminologi Indonesia", vo;.3, Number.1, June, 2003, pp.45. http://journal.ui.ac.id, accessed on August 29, 2017

[9] Nurcholish madjid, Indonesia Kita, Jakarta: Gramedia Pustaka Umum Paramadina University and Perkumpulan Membangun Kembali Indonesia, 2004

[10] S.Budhisantoso, Pancasila dan kebangaan dalam Mayarakat Majemuk dengan Keanekaragaman Kebudayaan, in Ketahanan Nasional Journal,VII (2), August 2002, pp.19, htps.//journal.ugm.oc.id, accessed on August 2017

[11] Tarmizi Taher, Anatomi Radikalisme Keagamaan dalam Sejarah Islam, in Bakhtiar Effendi and Hendro Prasetyo (Ed.), Radikalisme Agama, Jakarta: PPIM-IAIN , 1998

[12] Tarmizi Taher, Anatomi Radikalisme,p.34 see also Gilles, The revenge of God, Chambridge: The Polity Press, 1994

[13] Tarmizi Taher, Radikalisme Agama: sebuah Pengantar, Jakarta: Pusat Pengkajian Islam dan Masyarakat (PPIMIAIN), 1998

[14] Usman Quraisy, Good governance dalam Perspektif nahdlatul Ulama dan Muhammadiyah, Jambi: Syari'ah Press

[15] Yudi Latif, Negara Paripurna: Historisitas, Nasionalitas dan Aktualitas pancasila, Jakarta: PT.Gramedia Pustaka Utama, 2011 